\title{
銀行建物の用途変更に関する研 A STUDY ON CONVERSIONS OF 究 BANK BUILDINGS IN JAPAN
}

曾根陽子

安藤真由子

キーワード :

用途変更，都市銀行，合併，空き建物

Keywords:

Conversion, City banks, Merger, Vacant buildings
Yoko SONE $* 1$

Mayuko ANDO $* 2$

This research investigated about conversion of bank buildings. To 2006 from 1996, eleven city banks merged into five and many branches closed or merged. As a result many vacant buildings were produced. Most of these vacant buildings had big spaces for entrance hall and reception desk and placed at the center of downtown, near the station or on the main street. This investigation is clarified how vacant bank buildings were converted.

\section{1. 研究目的}

用途変更は、ある用途の建物が空き建物となることによって生じ る。空き建物の発生要因は、公共建築では地域需要との質的・量的 粗龉が多く、民間建物では企業又は個人の経済活動との不適応が多 い。そして双方に共通寸る発生要因には市町村合併や法制度の変更、 企業統廃合による施設配置の編成変えがある。平成大合併に伴う公 的集会施設の統廃合については既発表 ${ }^{1)}$ のとおりだが、企業の統廃 合に伴う空き建物の利用実態については明らかにされていない。

本研究は、近年大規模合併が行われた銀行の建物に着目し、組織 改編に伴って生じた空き建物の用途変更の実態を明らかにし、空き 建物運用の決定プロセスの問題点を示すものである。銀行は民間企 業であるが、その建物は都市空間において重要な位置を占めており、 建物も堅牢なものが多いので、その活用の実態と問題点を指摘する ことは我が国の民間建物のストック活用を検討する上で有用な基礎 資料を提供することになる。

\section{2. 銀行建築の特徵と近年の傾向}

銀行は地域の商業活動、経済活動の中心的な役割を果たしており、 その建物は繁華街や駅周辺などの市街地中心や主要道路に面する立 地特性を持っている。外観は金融機関の安定性と威厳を示す立派な 構えを持ち、内部空間は建築設計資料集成 ${ }^{2)}$ に示されるように業務 執行の大空間と待機中の多人数客が滞留する大規模客溜りがあった。

しかし現在、ATM やインターネットロ座の普及、コンビニへの ATM 設置などの業務機械化と共に空口業務は分散化・小規模化されてき た。その結果、旧来のように中心地に大きな構えを持つ建物は不要 となり、内部空間も諸室の中心的な存在であった大きな客溜り空間
が不要になり、小スペースでの銀行運用が可能となった。

同時に金融再編成が進行し、図 1 に示寸とおり 1996 年以降、11 社の都市銀行が 4 社に統合され、これにより店舗の大規模な統廃 合・再編成が行われた。それに伴って、多くの銀行建物にも撤去や 用途変更が行われた。このことは、筆者の 1 人が委員として調查を 提言した東京消防庁の調查結果注 1 ) から確認することができる。表 1 は 2002 年、2003 年の消防同意で、用途変更受理処理を行った事例 の変更前と変更後の用途である。変更前用途の最多は事務所の 301/472 件 (64\%) で、現存建物数を反映している。第 2 位が銀行で $(102 / 472: 22 \%)$ 、それ以外の用途の建物数を大きく上回っているこ とから、銀行建物の用途変更がこの時期極めて多かったと分かる。

\section{3. 既往研究}

同本論に関係する既往研究には、筆者の 1 人が行った公共建築の 用途変更の傾向と要因に関する研究 ${ }^{3}$ や、コンバージョンの実施可 能性評価に関寸る佐藤考一らの研究 ${ }^{4)}$ 、用途変更時に妨げとなりう る建築関連法規を抽出し、問題解決の提案を行った河野学らの研究 5)がある。学術講演梗概集には、井川充司らの公共集合住宅のスト ック研究 ${ }^{6)}$ 、太田俊彦らの公共施設の用途変更の研究 ${ }^{7)}$ 、平田哲 の廃校の用途変更に関する研究 ${ }^{8)}$ 、中村光将らのホテルの有効利用 に関する研究 ${ }^{9}$ 、佐藤考一らのオフィスビルの空室率やフィージビ リティースタディーの研究 ${ }^{10)}$ などがある。だが、本研究同様の組織 編成の変更に伴う民間建物の用途変更に焦点を当てた研究は見られ ない。

\section{4. 建築関連雑誌にみる銀行建物の用途変更}

1966 年〜1998 年の 32 年間に、建築関連雑誌注 2) に掲載された用

\footnotetext{
日本大学生産工学部建築工学科 教授・工博

（干 275-8575 習志野市泉町 1-2-1）
}

2 デルフト工科大学大学院 修士（工学）
'1 Prof., Dept. of Architecture Engineering, College of Industrial Technology, Nihon Univ., Dr. Eng.

Master's course, Graduate School of Technology Univ. of Delft 
途変更事例は 761 件あり、その中で銀行建物の用途変更事例は 14 件注3) あった。著名建物の歴史的保存目的の用途変更事例もあるが、 建築関連雑誌掲載という性質から、銀行建物の外観や内部空間の特 徵を活かして、博物館やバー、ホテルなどに用途変更して有効活用 した事例がほとんどであった。

\section{5. 調査方法}

5 - 1. 日本金融名鑑による調査 2005 年 5 月〜 月

日本金融名鑑 ${ }^{11)}$ の、1996 年版には記載があるが、2006 年版には 記載がない店舗を再編による廃止店舗とみなした。都市郊外の支店 の場所に千葉県、地域中心店の多い場所に横浜市中区・西区、本店 の多い場所に東京都千代田区・中央区を選び、調查対象地とした。 その結果 187 店が抽出された。なお 2006 年度金融名鑑はU F J 銀 行・東京三菱銀行の合併前の資料である。支店が同一建物内に複数 入っている場合は、重複を避けるため建物の数を支店数とした。

$5-2$. 現地調查 2005 年 8 月〜 2006 年 12 月

抽出事例の閉鎖後の使用内容は、現在の住宅地図でも当該銀行へ の電話でも確認できなかったので、名鑑に記載されていた住所に行 き、近所の店舗や交番で閉鎖銀行の場所と建物を特定し、現在の使 用内容を確認した。閉鎖の 187 店中 140 店は確認できたが、残り 47 店は当時の住宅地図でも、近所の人達に聞いても銀行だった建物(部 分）が確認できなかった。1 40 店の地域別内訳は、東京都中央区 39 店、千代田区 54 店、横浜市中区 7 店、西区 7 店, 千葉県 33 店である。 $5-3$. ヒアリング調查 2006 年 12 月

閉鎖銀行建物の廃止後の撤去・用途変更等の計画・設計経緯を知 るため 2006 年 12 月、ゼネコン 2 社の銀行建物担当者と銀行建物の 用途変更をした設計事務所 1 社の担当者にヒアリング調查を行った。

\section{6. 調査結果}

$6-1$ 閉鎖した店舗

1996 年度版金融名鑑にあって 2006 年度版にはなくなった閉鎖店 舗は表 2 に示寸とおりである。調查対象地区全体で見ると、再編前 1996 年には 369 店あったのが、再編後の 2006 年には 182 店になっ ており、ほぼ半数 187 店 $(51 \%)$ の店舗が閉鎖されている。

店舗の減少率が高いのは、千葉県や横浜 2 区などの地方都市より も東京の中心地で、東京都千代田区は 104 店あった支店が 32 店に減 少し、69\%(72/104)の店舗が閉鎖している。中央区も 112 店あった 支店が 46 店に減少し、59\% (66/112) が閉鎖されていた。このことか ら、この $2 つ の$ 地域が銀行の密集地域であり、統廃合による減少効 果が最も高かった地域であったことが分かる。

\section{6-2 閉鎖後の建物撤去の有無}

現地確認された 140 店で、撤去された建物と取り壞されずに用途 変更された建物の比率は表 3 に示寸とおりである。全体では 118 店 が用途変更され $84 \%$ を占めていた。千葉県に比して東京の 2 区と横 浜の 2 区の撤去率が低い。市街地中心の店舗は、テナントビルに入 っている事例が多く、銀行の店舗閉鎖後も建て替えが発生していな いためである。テナントビルでない場合でも市街地中心部では、す でに建物が高容積で建てられていることが取り壊されない理由と考 えられる。

\section{$6-3$ 用途変更後の用途}

用途変更後の使用内容は、図 2 に示すように多岐にわたる。事務 所が 10\%(12/118) と最も多い。旧用途に近い、他社銀行、証券会社、
保険会社等が使用しているケースが $24 / 118$ と約 2 割を占めているが、 これらは確認申請の必要がない。店舗への用途変更も多く、各種店 舗を合計すれば $48 \%(57 / 118)$ と半数近い。内容的には本屋、薬屋、 コンビニエンスストアー、パチンコ屋などで、中心市街地にある立 地特性を生かしている。学習塾や各種学校、診療所など特定客を対 象とする用途は 6\% (7/118) であった。公共的用途は交流館 (集会施 設) 1 件のみで、レンガ造の建物の歴史的保存である。

図 2 を地域別に見たのが図 3 である。事務所 12 件中の 11 件と、 店舗では飲食店 (8)が都心 2 区にあり、ショールーム 4 件中 3 件は中 央区にある。また千葉県の薬局 (4) はいずれもチェーン店であり、こ の種の薬店は銀行の空き建物を意図的に新店舗展開に利用する方針 であったと思われる。また、空き状態で置かれている 6 件中 5 件は 千葉県で、地方都市の中心にある銀行でありながら、都心ほど銀行 廃止後の利用を緊急としない状沉が伺える。

\section{$6-4$ 建て替え後の用途}

撤去後建て替えられた建物は 22 件あり、建て替え後の建物用途は、 複合ビルとマンションがそれぞれ $27 \%$ (6/22 件) と多い。近所での聞 き取り調査によると、これらの建物は銀行時代に比べ容積率が非常 に高くなっているという話であった。パチンコ店や駐車場、倉庫、 空き地になっているところはいずれも千葉県で、土地の有効利用二 ーズが他の地域に比べ重視されていないことが分かる。

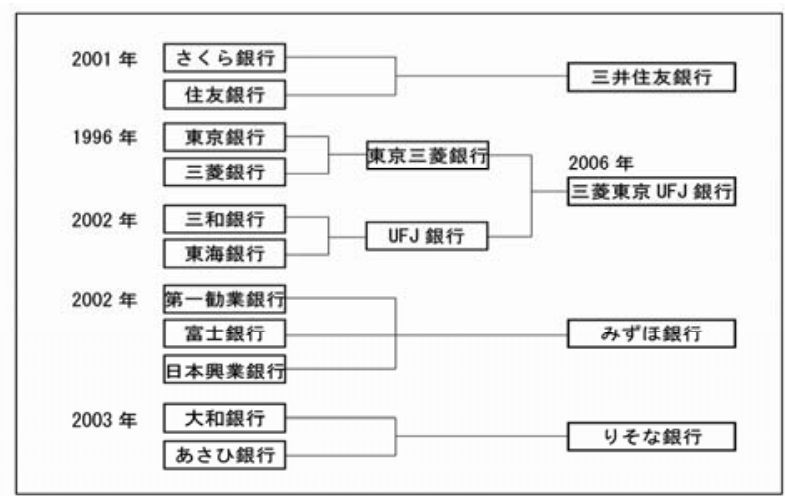

図 1 都市銀行再編図

表 1 用途変更前後の建物用途（東京消防庁）注 1)

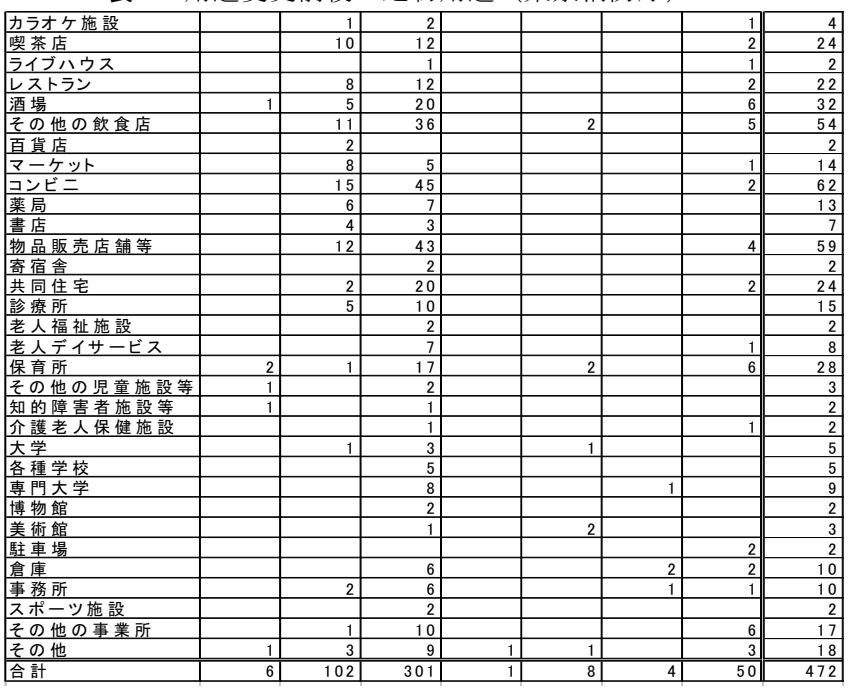

表 2 地域別閉鎖店舗

\begin{tabular}{|c|c|c|c|c|c|}
\hline & 中央区 & 千代田区 & 横浜2区 & 千葉県 & 計 \\
\hline 1996年度版 & 112 & 104 & 34 & 119 & 369 \\
\hline 2006年度版 & 46 & 32 & 18 & 86 & 182 \\
\hline 閉鎖店舗数 & $66(59 \%)$ & $72(69 \%)$ & $16(47 \%)$ & $33(28 \%)$ & $187(51 \%)$ \\
\hline
\end{tabular}


表 3 地域別閉鎖後建物の撤去の有無

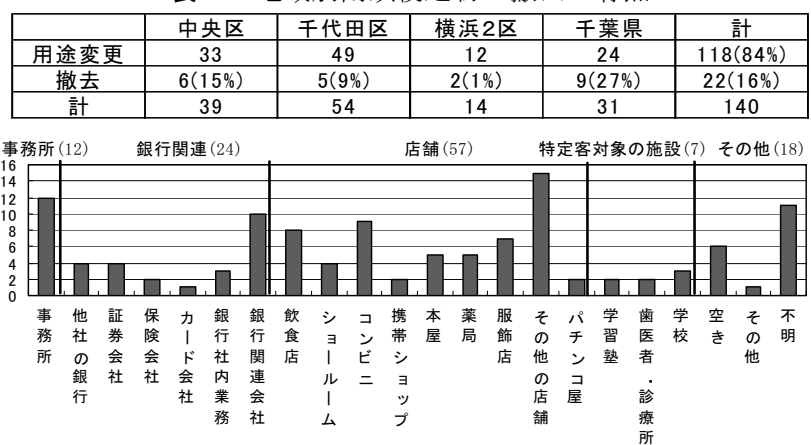

図 2 全体の変更後

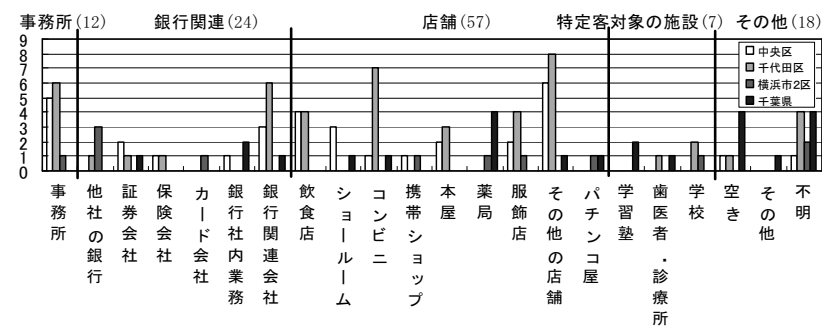

図 3 地域別の変更

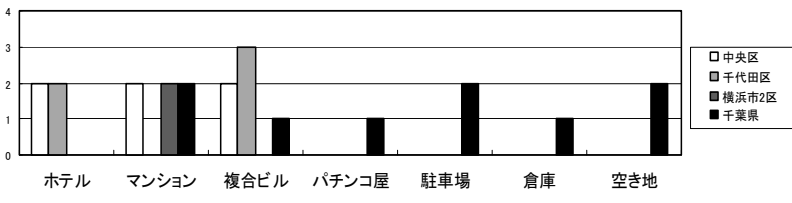

図 5 地域別の変更後用途

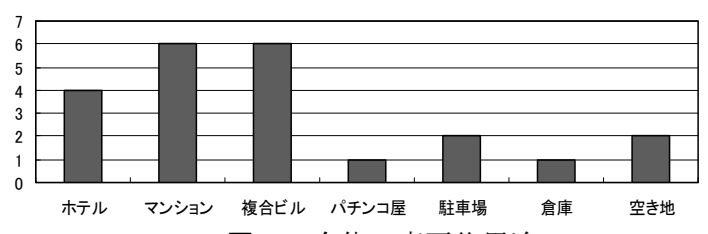

図 4 全体の変更後用途

\section{7. 元の建物の所有者別にみた傾向}

前項まで店舗閉鎖後の用途内容を分析したが、建物を現地確認す ると、銀行という旧用途の影響より、元の建物の所有者によって、 統廃合後に生じた空き建物の処遇が違ってくることが分かった。そ れらは以下の 6 つに分類できる。

(1)他社ビルにテナントとして入っていた場合

今回抽出して現地確認した銀行の $68 \%$ (95/140 件) が、他社が所有 するビルにテナントとして入っていた。従って銀行支店閉鎖後も建 物自体に変更はなく、銀行が入っていた部分が他の店舗へ用途変更 されていた。このケースの多くは銀行がビル建設当初からテナント として入るよう設計されている場合が多いため、1 階の大通りに面 する立地特性のほか、高い階高、腰壁のあるFIX 空とガラス張りの エントランス、壁が少ない大空間などの空間特徵を持っている。そ のため本屋やパチンコ屋、コンビニエンスストアー等大空間を必要 とし、かつ不特定多数の客を呼び入れる店舗に変更されている例が 多い。しかし、旧用途が銀行であっても、銀行特有の威厳があるつ アサードを有している建物は 1 件だけであり、銀行としての機能的 条件以上の、昔の銀行に求められたような威厳あるファサード印象 はテナントビルの銀行には求められていなかった。

(2)複合テナント自社ビルの場合

自社ビルといっても銀行自体が建物を持つのではなく、M 銀行は M
地所、S 銀行は S 不動産のように、関連不動産会社が建物を所有す る(それを以下自社ビルと呼ぶ)。その建物に他企業も入っている複 合テナントビルの場合が、今回の事例では $7 \%(10 / 140$ 件) あった。支 店閉鎖後は、当該銀行関連会社であるカード会社や保険会社、証券 会社などが使用する場合と、新たなテナントとして本屋やショール 一ムなど他の店舗を入れる場合がある。後者の場合は(1) 同様に立 地特徵と内部空間を考えた用途変更が多い。

(3)単独用途自社ビルの場合

前記同様の自社ビルだが、比較的小規模な建物で銀行だけの単独 用途だった場合は、支店廃止後に建物全体の用途変更が行われる。 今回の調查では $6 \%(9 / 140$ 件)がそういうケースであった。このケー スでは、支店閉鎖後も銀行関連会社が引き続きビルを所有する場合 と他社に建物を売却する場合がある。前者ではビルに手を加えず証 券会社やカード会社などの関連業務用途になるが、後者では購入さ れた後新しい用途に合わせるため改築が行われている。ファサード を変えて服飾店やチェーン店薬局に用途変更する例や、歴史的建造 物をファサード保存し、建築家によって内部を改築し大学院に用途 変更寸る例などが見られた。単独用途の場合、元の建物が銀行機能 の建物として建てられているため、金庫など特殊な空間を持つが、 それらの撤去は構造的問題があり用途変更後も倉庫・客室等そのま まの形態で使用されている。

(4)解体・撤去される場合

$16 \%$ (22/140 件)の建物は閉鎖後に解体撤去され、建て替え又は駐 車場として使用されていた。東京 2 区で取り壊された場合 (11件) は、 立地の良さから土地の効率的な使用が求められ、元の建物よりも容 積率が高くなって、マンションやホテル、複合ビルなどに建て替え られている。東京駅近くの著名建築家設計の旧日本相互銀行建物も 例外ではなく近々建て替え予定という。解体理由は建物の老朽化や 用途変更が困難、土地売却相手の要望、等々複数の要因があるが、 経済性の点から高容積にせざるを得ないということである。都心と 比較すれば土地費の安い千葉県では駐車場や倉庫として使用される ケースや、容積率が低い建物に建て替えるケースもある(6 件)。

(5)歴史的保存対象の自社ビル一復元

$1 \%$ (2/140 件)の建物は、歴史的な建造物を一度取り壊し、景観保 存の目的でマンションやオフィスビルなど容積率の高い建物にして 部分保存されていた。横浜市中区の例では復元された歴史的建物が、 マンションの低層階を囲み内部で一体型になっている。「Bank Art 1929」に使われている美術館も同様な部分保存であり、昭和初期以 前に建てられた建物の用途変更に見られるケースである。

(6)資産価值の低い自社ビル--放置

$4 \%$ (5/140 件)の建物は自社ビルで、現在空き状態で放置され、解 体または用途変更が決められていない状態である。このケースは、 千葉県でのみ見られた。

\section{JR 船橋駅前の事例}

JR 船橋駅前を例に、銀行の統廃合によって変化した駅前の状況を 示寸 (図 6)。ここには 1996 年当時、半径 $300 \mathrm{~m}$ 以内に 8 店の銀行支 店が存在した。しかし2006 年には、駅から離れた 2 支店が廃止され、 2 支店が駅前に出来た複合ビル内に移転した。廃止または移転した 4 支店の内 2 支店は取り壊され、現在駐車場と空き地になっている。 取り壊されなかった 2 店の建物は自社ビルで、 1 店は 1 階に ATM を 
残し他のフロアーを社内業務に使い、もう 1 店はATM コーナーだけ 設置して他のフロアーは使用していなかった。

\section{9. 統廃合に伴う建物用途等の決定経緯}

銀行建物の計画・設計担当者に、銀行統廃合後の建物に関寸る計 画・設計経緯についてヒアリング調査を行った結果、図 6 に示すよ うなフローが描けることが分かった。

銀行の統合が決まるとまず銀行の全体方針が決められ、本店・地 域中心店・支店・営業所・出張所などのネットワーク (人員・スペー ス)の再編が行なわれる。これにより重点地域が決定し、各地域範囲 と地域ごとの支店廃止数が決まる。次に、支店縮小地域にある建物 それぞれの法的条件・経営状態・耐久性等がリストアップされ、収 支設計が行われて、廃止、売却、その後の使い方が大まかに決まる。 ここで空きスペースの大枠が決定する。空きスペースが他社ビルの 場合は継続借用と返却があり、自社ビル（区分使用+全体使用）の場合、 諸調査とマーケティング、テナント探しなどが並行して行われ、複 数案の可能性が検討される。その後、ゼネコンや設計事務所に具体 案の検討が依頼され、収支設計がなされ、新たなテナントによるマ 一ケティングや収支設計の結果と照合し、撤去か用途変更かが決定 する。
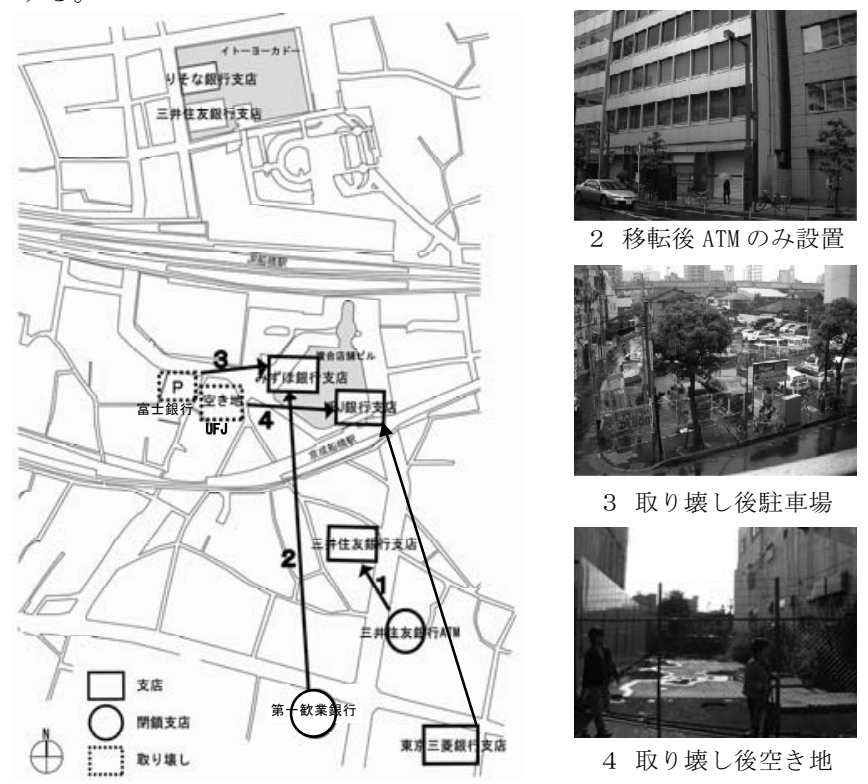

3 取り壊し後駐車場

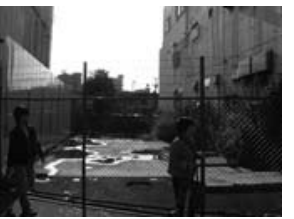

4 取り壊し後空き地

図 6 JR船橋駅前における銀行の統廃合

\section{0. まとめ}

上述のように現在のところ、銀行の建物では 2 段階で行なわれて いるいずれの収支設計においても建物自体の価值が考慮されること はなく、主に収益性によって建物の使われ方が決定されている。し かし、中心市街地に大きな位置を占めていた銀行建物は、立地や建 物特性を活かした用途変更が考慮されるべきであった。そのために は、第一段階の建物に関寸る基本方針決定時と第二段階の判断基準 には建物自体の価值を反映する視点をいれること、また土地建物の 調查時には築年数や修繥費用だけでなく建築的価値を調查すること、 事業可能性の検討時には複数案の中に必ず既存建物活用案を入れる こと、などが望まれる。中央郵便局の保存が話題になったが、民間 企業であっても、建物自体は社会的存在としての意味があるので、 採算性だけでなく、存在する建物の価值を検討することは企業の社 会的責任である。

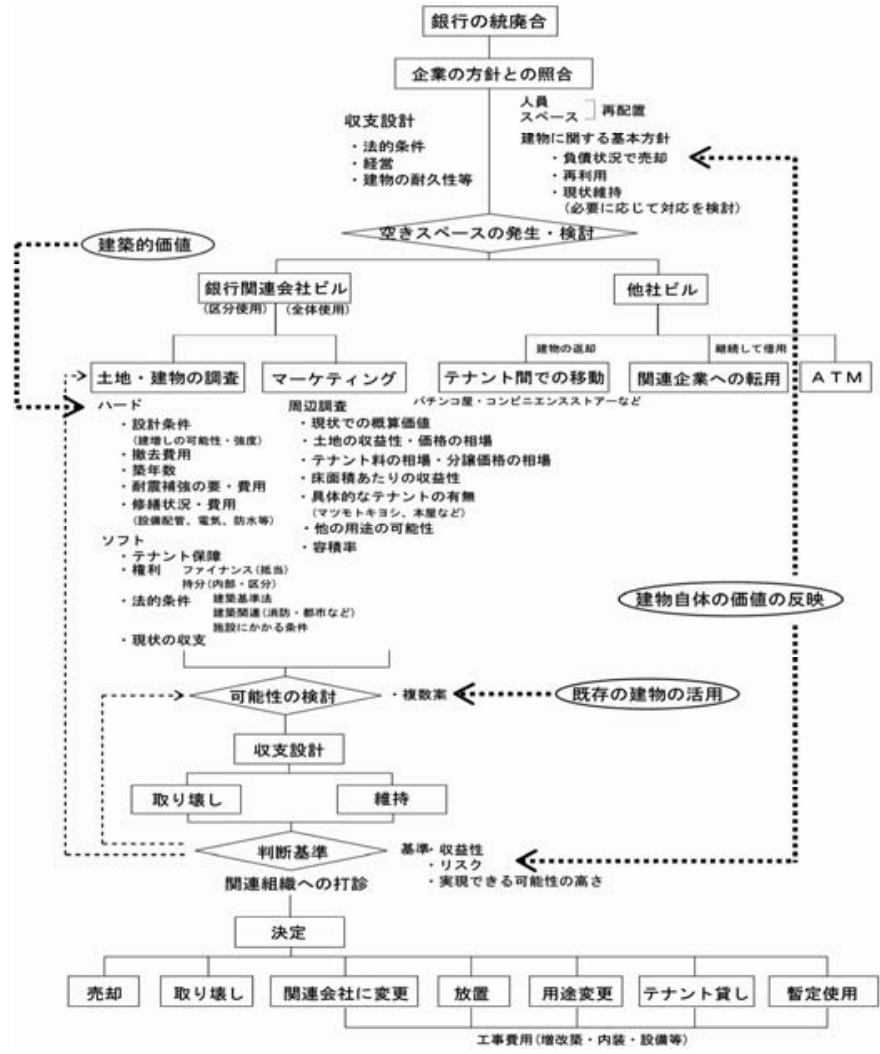

図 7 統廃合に伴う建物用途等の決定経緯

\section{参考文献}

1）安藤真由子、曽根陽子、加藤福、浅野平八 : 社会教育法改正に伴う公民館 の変更と用途変更に関する研究、日本建築学会学術講演梗概集 E-1、pp. 495 $\sim 496 、 2005$

2）建築設計資料集成 8 建築一産業、日本建築学会、1981

3）曽根陽子: 公共建築における用途変更の傾向と要因 公共建築の機能変更 に関する研究その 1 、日本建築学会計画系論文報告集 No. 403 1989 年 9 月

4）佐藤考一、松村秀一、西瑠衣子：コンバージョンの実施可能性評価に関す 万研究、日本建築学会計画系論文報告集 No. 597 pp. 31 36、2005 年 11 月

5）河野学、吉村英祐、飯田匡; 用途変更時の建築関連法規の抵触事項に対寸 る設計者の意識調査に基づく規制緩和の可能性に関する考察、日本建築学 会計画系論文報告集 No. 626 pp. 729 735、2008 年 4 月

6）井川充司、門脇耕三、深尾精一: 大阪府住宅供給公社による集合住宅ス卜 ックの概況、日本建築学会学術講演梗概集 E-1 pp. 531〜 532、2002

7）太田俊彦、角田誠: 都区内公共施設の用途転用に関する調查研究、日本建 築学会学術講演梗概集 E-1 pp. 545 546、2002

8）平田哲、稲垣淳哉、平瀬有人、古谷誠章: 学校建築研究一廃校リノベーシ ヨンに見る学校制度・空間研究、日本建築学会学術講演梗概集 E-1 pp. 77 〜 79、 2004

9）中村光将、高井宏之：過去 10 年間に変更・閉鎖された事例の実態と計画 特性 閉鎖・変更されたホテルの有効利用に関する研究 その 1 、日本建 築学会学術講演梗概集 E-1 pp. 37〜 40、2005

10）佐藤考一、小見康夫、新堀学、田村誠邦、松村秀一：東京におけるコン バージョンのフィージビリティースタディー、日本建築学会学術講演梗概 集 E-1 pp. 57〜60、2005

11）日本金融名鑑 下巻 1996 年 $\boldsymbol{*} 2006$ 年、日本金融通信社

注

注 1）『社会情勢の変化等に伴う性能評価に即した既存建築物の火災危険要 因の解明と防火安全対策のあり方一火災予防審議会答申-』平成 17 年 3 月 東京消防庁火災予防審議会

注 2）新建築 新建築社、 $\mathrm{a}+\mathrm{u}$ 新建築社、SD 鹿島出版社、建築文化 彰国 社、住宅建築 建築資料研究社、住宅特集 新建築社、日経アーキテクチ ヤー 日経 BP 社、1966 年 1998 年

注 3）神戸市立博物館、京都・雪月花、小樽ホテル、ホテルニュー函館など [2008 年 8 月 29 日原稿受理 2009 年 4 月 3 日採用決定 $]$ 